\title{
Ginsenoside Rg1 attenuates invasion and migration by inhibiting transforming growth factor- $\beta 1$-induced epithelial to mesenchymal transition in HepG2 cells
}

\author{
MEILING YU ${ }^{1,2^{*}}$, XIAOBING YU ${ }^{3 *}$, DAOHUA GUO ${ }^{1,2}$, BINBIN YU $^{2}$, LI LI $^{3}$, QIAO LIAO ${ }^{2}$ and RONG XING ${ }^{1,2}$ \\ ${ }^{1}$ Department of Pharmacy, The First Affiliated Hospital of Bengbu Medical College, Anhui, Bengbu 233004; \\ ${ }^{2}$ Faculty of Pharmacy, Bengbu Medical College, Anhui, Bengbu 233030; ${ }^{3}$ Department of Pharmacology, \\ Zhongshan School of Medicine, Sun Yat-Sen University, Guangzhou, Guangdong 510080, P.R. China
}

Received February 18, 2014; Accepted November 19, 2014

DOI: $10.3892 / \mathrm{mmr} .2014 .3098$

\begin{abstract}
Ginseng has become one of the most commonly used alternative herbal medicines and its active component, ginsenoside Rg1, possesses known pharmacological effects, including anticancer properties. However, the effects of ginsenoside $\mathrm{Rg} 1$ on metastasis have not been investigated. The present study demonstrated that ginsenoside Rg1 was able to suppress transforming growth factor- $\beta 1$ (TGF- $\beta 1$ )-induced invasion and migration in HepG2 liver cancer cells. This suppression was associated with the inhibition of TGF- $\beta 1$-induced epithelial to mesenchymal transition (EMT).Furthermore, TGF- $\beta 1$ induced HepG 2 cells to undergo EMT and significantly promoted cell invasion and migration. When cells were pretreated with ginsenoside Rg1 for $24 \mathrm{~h}$ and subsequently exposed to TGF- $\beta 1$ for $24 \mathrm{~h}$, the results demonstrated that ginsenoside $\mathrm{Rg} 1$ inhibited the initiation of TGF- $\beta 1$-induced EMT. In addition, HepG 2 cells exhibited a mesenchymal phenotype when exposed to TGF- $\beta 1$, but when exposed to ginsenoside Rg1 this effect was reversed and the cells exhibited a classical epithelial morphology. Ginsenoside Rg1 also increased the expression of the epithelial phenotype marker E-cadherin and repressed the expression of the mesenchymal phenotype marker vimentin. In conclusion, the results of the present study suggest that ginsenoside Rg1 may suppress liver cancer invasion and migration in vitro through inhibiting TGF- $\beta 1$-induced EMT.
\end{abstract}

Correspondence to: Professor Rong Xing, Department of Pharmacy, The First Affiliated Hospital of Bengbu Medical College, 287 Changhuai Road, Anhui, Bengbu 233004, P.R. China

E-mail: xingrong9796@163.com

*Contributed equally

Key words: transforming growth factor- $\beta 1$, epithelial to mesenchymal transition, ginsenoside $\mathrm{Rg} 1$, invasion, migration

\section{Introduction}

Hepatocellular carcinoma is a major health problem worldwide and the third largest cause of cancer-associated mortality in the world annually (1). Metastasis remains a continuing problem for the management of liver cancer. The multi-step process of metastasis includes local invasion, intravasation to the lymph and blood systems, survival in the bloodstream, extravasation from the microvessels and colonization at a secondary site $(2,3)$. There is evidence to suggest that epithelial to mesenchymal transition (EMT) contributes to cancer progression, invasion and migration in various types of cancer $(4,5)$. EMT is a cellular process during which epithelial polarized cells become motile mesenchymal-appearing cells (6). The hallmarks of EMT include loss of cell-cell adhesion, actin cytoskeleton reorganization and acquisition of increased migratory characteristics. EMT is characterized by the downregulation of epithelial differentiation markers, including E-cadherin and the upregulation of mesenchymal markers, including vimentin.

EMT can be initiated by external signals, including fibroblast growth factor, epidermal growth factor (EGF) and transforming growth factor (TGF)- $\beta 1(7,8)$. TGF- $\beta 1$ is the multifunctional cytokine implicated in different biological processes by inducing EMT, such as during wound healing, fibrotic diseases, embryonic development and cancer pathogenesis (9). Commonly, tumor cells lose the ability to inhibit the growth activity of TGF- $\beta 1$.

There is increasing interest in the role of Traditional Chinese Medicine in maintaining health and treating disease. Ginsenoside Rg1, is one of most active and abundant components in ginseng, which has pharmacological effects in the central nervous system, cardiovascular system and immune system and also exerts anticancer properties (10-18). However, the effect of ginsenoside Rg1 on cancer metastasis has not been investigated. In the present study, the effects of ginsenoside Rg1 on TGF- $\beta 1$-induced invasion and migration in liver cancer were demonstrated and a potential mechanism for these effects was examined. It was hypothesized that TGF- $\beta 1$ induces HepG 2 cells to undergo EMT and promotes cell invasion and migration. Ginsenoside Rg1 may suppress 
liver cancer invasion and migration through inhibiting TGF- $\beta 1$-induced EMT.

\section{Materials and methods}

Materials. Ginsenoside Rg1 was obtained from Shanghai International Port (Group) Co., Ltd. (Shanghai, China) Sulforhodamine B (SRB), trichloroacetic acid (TCA), acetic acid, anti- $\beta$-actin and dimethyl sulfoxide were purchased from Sigma-Aldrich (St. Louis, MO, USA). Monoclonal rabbit antibodies for E-cadherin (1:1,000; \#3195) and vimentin (1:1,000; \#5741) were obtained from Cell Signaling Technology, Inc. (Danvers, MA, USA). Secondary monoclonal rabbit antibodies (1:5,000; PA1-14444) for western blotting were obtained from Amersham Biosciences Corp. (Piscataway, NJ, USA). All other reagents were obtained from Sigma-Aldrich unless stated otherwise.

$S R B$ assay. Cytotoxicity was determined using an SRB assay. Cells were seeded into 96-well plates and exposed to different concentrations of ginsenoside $\operatorname{Rg} 1$ (50, 100,200 and $400 \mu \mathrm{M})$. After $48 \mathrm{~h}$ of incubation, the cells were fixed with TCA for $1 \mathrm{~h}$ at $4^{\circ} \mathrm{C}$, air-dried and then stained with $0.4 \% \mathrm{SRB}$ solution for $30 \mathrm{~min}$ at room temperature. Following staining, the SRB solution was removed and cells were washed five times with $1 \%$ acetic acid. Subsequently, $10 \mathrm{mM}$ Tris base solution ( $\mathrm{pH}$ 10.5) was added to dissolve the protein-bound dye and plates were incubated on a plate shaker for $10 \mathrm{~min}$. The $\mathrm{OD}_{570} \mathrm{~nm}$ was determined using a 96-well plate reader (MRX; Dynex Technologies, Chantilly, VA, USA).

Wound-healing assay. Cells were cultured in a 6-well plate and incubated until they reached $80 \%$ confluence. Cell monolayers were carefully wounded by scratching with a $200 \mu \mathrm{l}$ sterile plastic pipette tip. Subsequently, cells were washed twice with phosphate-buffered saline and then replaced with fresh medium without serum. For each scratch, images were captured at 0 and $24 \mathrm{~h}$ using an inverted microscope (Nikon Eclipse TS100 1064; Nikon, Tokyo, Japan) in the same field.

Matrigel invasion assay. Invasion of HepG2 cells was performed in a $24-w e l l$ transwell unit ( $8 \mu \mathrm{M}$ pore size) and was coated with $1 \mathrm{mg} / \mathrm{ml}$ Matrigel matrix as described previously (19). Briefly, cells were placed on the Matrigel-coated transwell (the upper compartment of the invasion chamber), and cells were exposed to TGF- $\beta 1(1.25-5.00 \mathrm{ng} / \mathrm{ml})$ for $24 \mathrm{~h}$, or cells were pretreated with ginsenoside $\operatorname{Rg} 1(50-200 \mu \mathrm{M})$ for $48 \mathrm{~h}$ in the presence or absence of $5 \mathrm{ng} / \mathrm{ml}$ TGF- $\beta 1$ for $24 \mathrm{~h}$. The cells were then resuspended in $200 \mu \mathrm{l}$ serum-free medium and placed in the upper chambers at $5 \times 10^{4}$ cells Conditioned medium $(600 \mu \mathrm{l})$ was added to the lower compartment of the invasion chamber. Following incubation at $37^{\circ} \mathrm{C}$ for $48 \mathrm{~h}$, cells that had invaded the lower surface of the membrane were fixed with methanol and stained with hematoxylin and eosin. Random fields were counted by light microscopy (MF53; Olympus Corporation, Tokyo, Japan).

Western blotting. Cells were harvested and lysed for total cellular protein extraction and then centrifuged at 2,250 $\mathrm{x} g$ for $30 \mathrm{~min}$ at $4^{\circ} \mathrm{C}$. A DC protein assay kit was used to determine the protein concentrations (Bio-Rad, Hercules, CA, USA). Total protein $(25 \mu \mathrm{g})$ was separated using 8-12\% sodium dodecyl sulfate-polyacrylamide gels and subsequently transferred onto a polyvinylidene difluoride membrane. Following blocking with skimmed milk, the membranes were incubated with various primary antibodies, E-cadherin (1:1,000), vimentin $(1: 1,000)$ and $\beta$-actin $(1: 10,000)$, at $4^{\circ} \mathrm{C}$ overnight, respectively. Immunopositive bands were visualized using the Amersham ECL ${ }^{\mathrm{TM}}$ plus western blotting detection kit (GE Healthcare, Piscataway, NJ, USA).

Statistical analysis. Statistical analysis between groups was performed using an unpaired Student's t-test with Sigmaplot 10.0 software (Jandel Scientific, San Rafael, CA, USA). Data are presented as the mean \pm standard error of the mean. $\mathrm{P}<0.05$ was considered to indicate a statistically significant difference.

\section{Results}

TGF- $\beta 1$ induces HepG2 cells to undergo EMT. Initially, the optimum concentrations required for TGF- $\beta 1$ to initiate EMT in HepG2 cells were ascertained. Cells were treated with $1.25-5 \mathrm{ng} / \mathrm{ml}$ TGF- $\beta 1$ for $24 \mathrm{~h}$. Fig. 1 shows that the cells acquired a spindle-like fibroblastic phenotype and reduced their cell-cell contact when exposed to higher doses of TGF- $\beta 1(5 \mathrm{ng} / \mathrm{ml})$. Since EMT is closely associated with the loss of E-cadherin expression and acquisition of vimentin expression, the expression of E-cadherin and vimentin by western blotting was also assessed. The results demonstrated that TGF- $\beta 1$ decreased E-cadherin expression in a dose-dependent manner, while it significantly induced the expression of vimentin. The maximal effects of TGF- $\beta 1$ in initiating EMT in HepG2 cells were achieved at a concentration of $5 \mathrm{ng} / \mathrm{ml}$, therefore this concentration was used in subsequent experiments.

TGF- $\beta 1$ promotes the invasion and migration of HepG2 cells. Previous studies have demonstrated that EMT is involved in cancer invasion and metastasis, which are key processes in cancer progression and metastasis $(20,21)$. Thus, in the present study, the effect of TGF- $\beta 1$ on invasion and migration in HepG2 cells were assessed using transwell and wound-healing assays. Cells were exposed to different concentrations of TGF- $\beta 1(1.25-5 \mathrm{ng} / \mathrm{ml})$ for $24 \mathrm{~h}$. The results demonstrated that TGF- $\beta 1$ significantly promoted HepG2 cell invasion and migration compared with the untreated cells (Fig. 2A, B and C).

Ginsenoside Rgl inhibits TGF- $\beta 1$-induced cell invasion and migration. In order to observe the effect of ginsenoside $\mathrm{Rg} 1$ on cell viability in HepG2 cells, cells were treated with increasing concentrations of ginsenoside $\operatorname{Rg} 1(50-400 \mu \mathrm{M})$ for $48 \mathrm{~h}$ and then assessed using an SRB assay. Ginsenoside Rg1 had no effect on cell viability up to a concentration of $400 \mu \mathrm{M}$. Thus, the non-cytotoxic concentrations of ginsenoside $\mathrm{Rg} 1$, between 50 and $200 \mu \mathrm{M}$ were used in subsequent experiments (Fig. 3A).

To investigate the effects of ginsenoside $\mathrm{Rg} 1$ on TGF- $\beta 1$-induced cell invasion and migration, transwell 


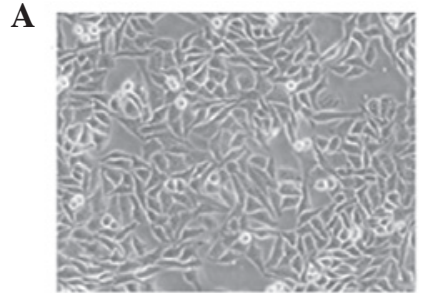

Control

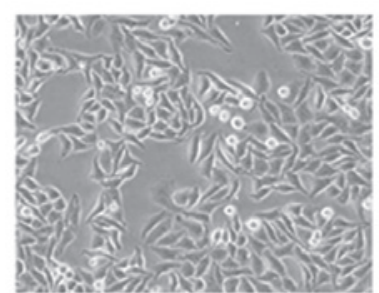

$1.25 \mathrm{ng} / \mathrm{ml}$

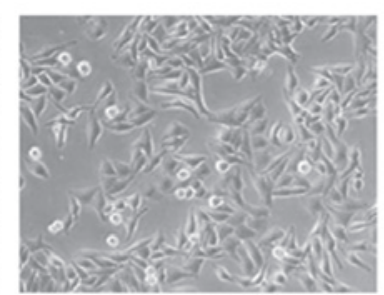

$2.5 \mathrm{ng} / \mathrm{ml}$

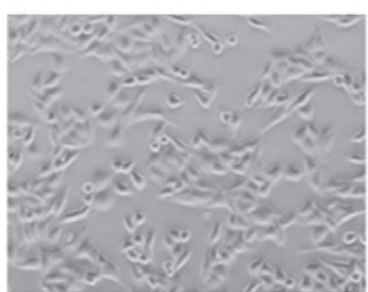

$5 \mathrm{ng} / \mathrm{ml}$

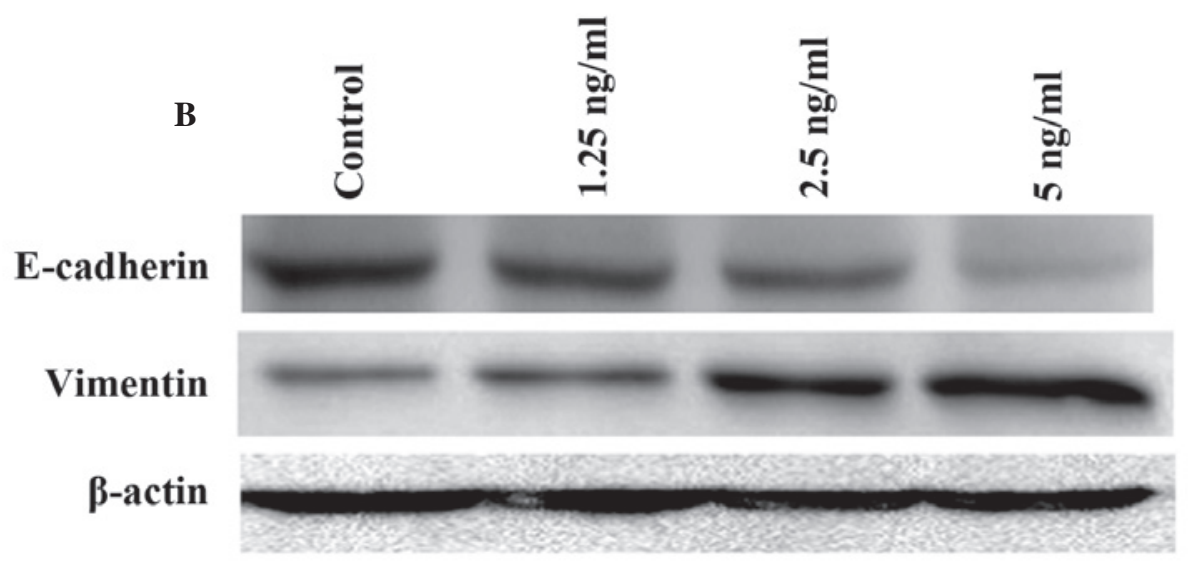

Figure 1. TGF- $\beta 1$ induces HepG2 cells to undergo epithelial to mesenchymal transition. HepG2 cells were exposed to different concentrations of TGF- $\beta 1$ (1.25-5 ng/ml) for $24 \mathrm{~h}$. (A) Images showing the morphological alterations of HepG2 cells following exposure to TGF- $\beta 1$. (B) Cellular protein levels of E-cadherin and vimentin were measured using western blotting. TGF- $\beta 1$, transforming growth factor- $\beta 1$.

and wound-healing assays were performed. Cells were treated with ginsenoside $\operatorname{Rg} 1(50-200 \mu \mathrm{M})$ for $48 \mathrm{~h}$ with or without $5 \mathrm{ng} / \mathrm{ml} \mathrm{TGF}-\beta 1$ for $24 \mathrm{~h}$. TGF- $\beta 1$ significantly increased invasion and migration of HepG2 cells compared with TGF- $\beta 1$-untreated control cells, while ginsenoside Rg1 reversed this effect (Fig. 3B, C and D). These results suggest that ginsenoside Rg1 may constitute an effective inhibitor of invasion and migration in HepG2 cells.

Ginsenoside Rg1 regulates morphological alterations and EMT marker expression during TGF- $\beta 1$-induced EMT. To further clarify whether suppression of TGF- $\beta 1$-induced invasion and migration by ginsenoside $\mathrm{Rg} 1$ resulted from regulation of EMT, the expression of EMT marker proteins vimentin and E-cadherin and alterations in cell morphology were examined. Fig. 4A shows that HepG2 cells exhibited a mesenchymal phenotype when exposed to TGF- $\beta 1$ ( $5 \mathrm{ng} / \mathrm{ml})$, but cells pretreated with ginsenoside $\mathrm{Rg} 1$ exhibited a classical epithelial morphology. The present study also analyzed the expression of the epithelial phenotype marker E-cadherin and the mesenchymal phenotype marker vimentin using western blotting. The results in Fig. 4B demonstrate that TGF- $\beta 1(5 \mathrm{ng} / \mathrm{ml})$ significantly decreased the expression of E-cadherin, but induced the expression of vimentin compared with TGF- $\beta 1$-untreated control cells, while ginsenoside $\mathrm{Rg} 1$ reversed these effects. These results suggest that ginsenoside Rg1 may prevent invasion and migration via inhibition of TGF- $\beta 1$-induced EMT in HepG2 cells.

\section{Discussion}

In the present study, the results demonstrated that ginsenoside Rg1 significantly suppressed TGF- $\beta 1$-induced invasion and migration. It is likely that the suppressive effects of ginsenoside $\mathrm{Rg} 1$ on invasion and metastasis are mediated through the inhibition of TGF- $\beta 1$-induced EMT. This indicated that ginsenoside $\mathrm{Rg} 1$ may be a potential inhibitor in preventing the invasion and migration of human liver cancer.

Tumor metastasis is a multi-stage process beginning with tumor cell migration and invasion. These proceses require EMT. During EMT, well-polarized and adhesive epithelial cells lose polarity and intercellular adhesion, which is mediated by cadherins. These cells then acquire a highly motile fibroblastoid or mesenchymal phenotype $(22,23)$. TGF- $\beta 1$ is major inducer of EMT and several studies have demonstrated that TGF- $\beta 1$ alone or in combination with other growth factors, including EGF and hepatocyte growth factor is critical in mediating EMT in various types of malignant tumor $(24,25)$. Consistent with these studies, the present study found that TGF- $\beta 1$ induces HepG2 cells to undergo EMT and the cells acquire a spindle-like fibroblastic phenotype and reduce their cell-cell contact. TGF- $\beta 1(5 \mathrm{ng} / \mathrm{ml})$ also significantly upregulated the expression of the mesenchymal marker vimentin, downregulated the expression of the epithelial marker E-cadherin and promoted invasion and migration of HepG2 cells. 
A

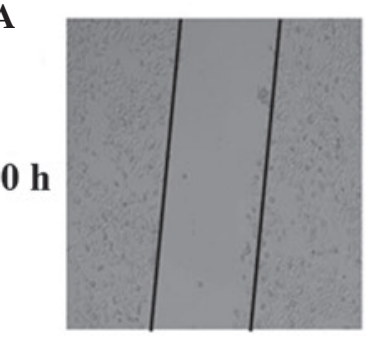

$24 \mathrm{~h}$

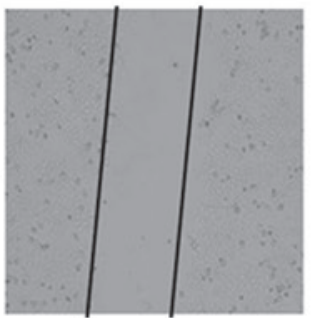

Control
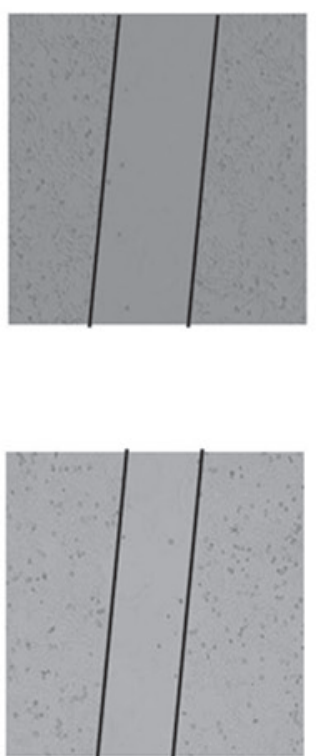

$1.25 \mathrm{ng} / \mathrm{ml}$
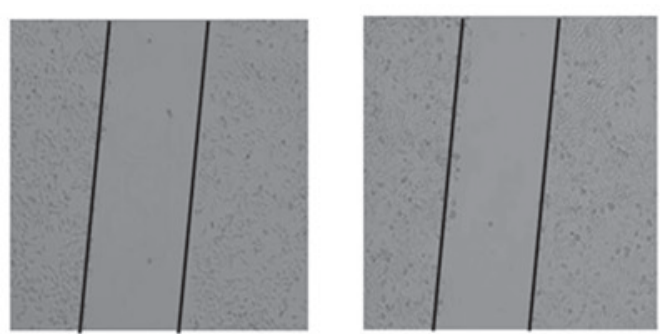

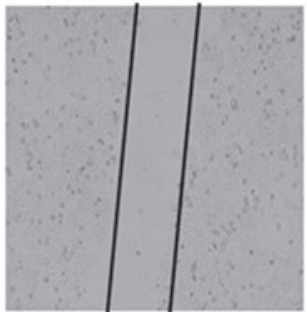

$2.5 \mathrm{ng} / \mathrm{ml}$

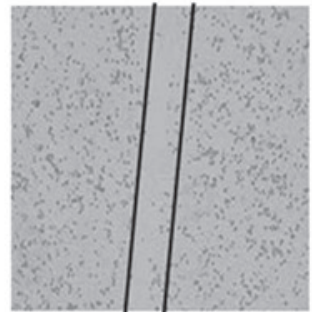

$5 \mathrm{ng} / \mathrm{ml}$

B

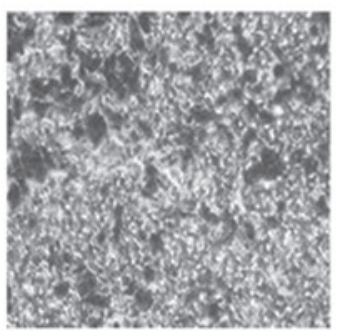

Control

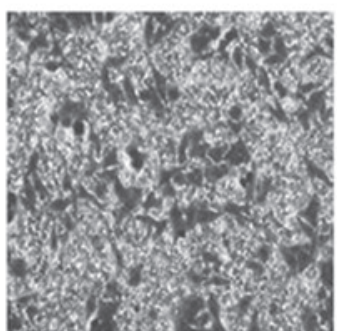

$1.25 \mathrm{ng} / \mathrm{ml}$

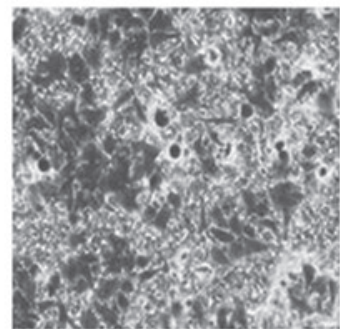

$2.5 \mathrm{ng} / \mathrm{ml}$

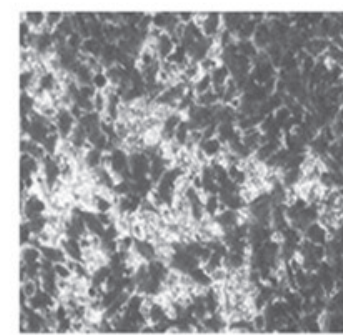

$5 \mathrm{ng} / \mathrm{ml}$

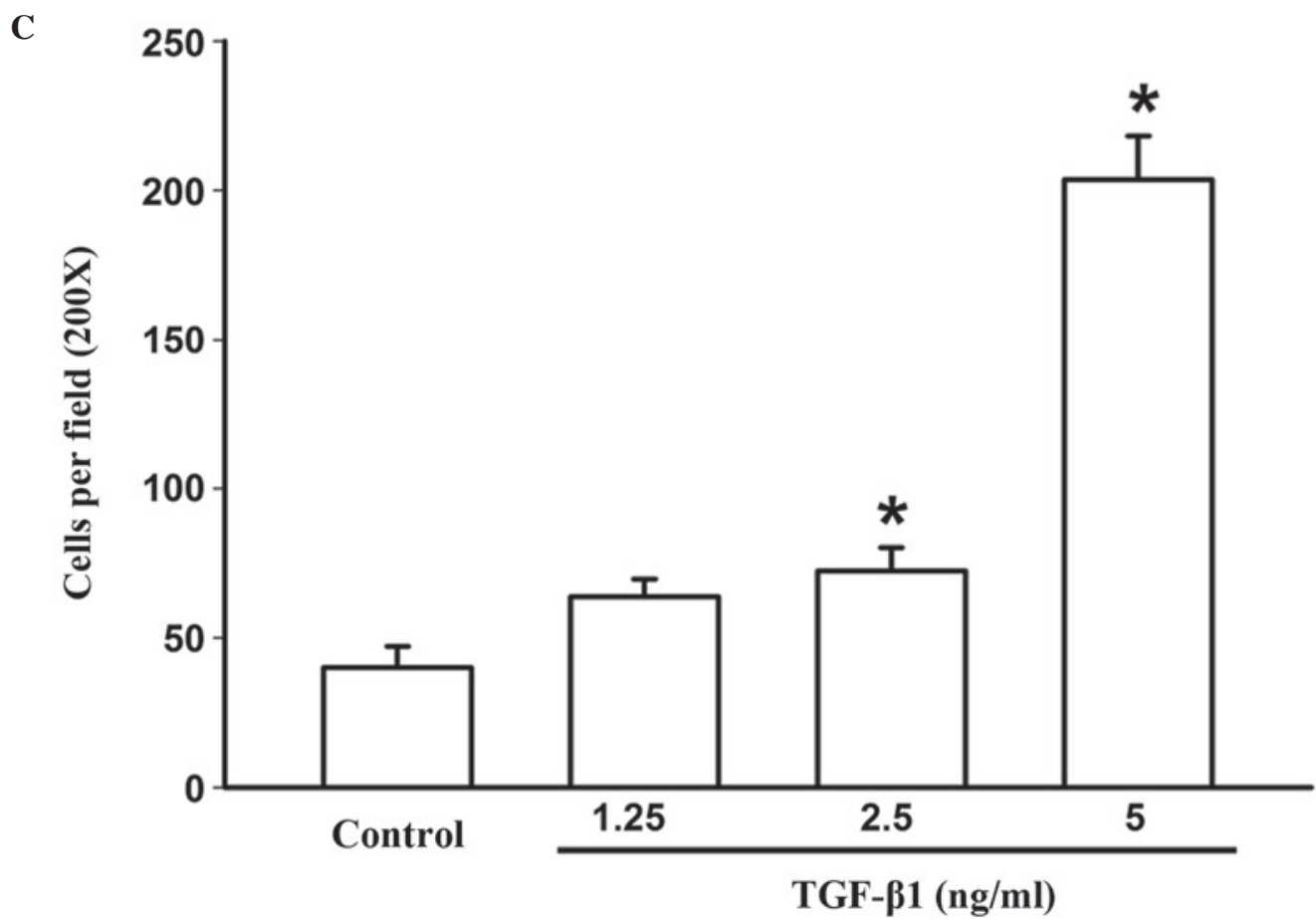

Figure 2. TGF- $\beta 1$ promotes the invasion and migration of HepG2 cells. HepG2 cells were exposed to different concentrations of TGF- $\beta 1$ (1.25-5 ng/ml) for 24 h. (A) Migration ability of HepG2 cells was analyzed using a wound-healing assay. Cells were scratched with a pipette tip and then exposed to TGF- $\beta 1$ $(1.25-5 \mathrm{ng} / \mathrm{ml}$ ) for $24 \mathrm{~h}$. (B and C) Invasive ability of HepG2 cells was assessed using a Matrigel invasion assay. Results are presented as the mean \pm standard error of the mean of three independent experiments. ${ }^{*} \mathrm{P}<0.05$ vs. control. TGF- $\beta 1$, transforming growth factor- $\beta 1$. 
A

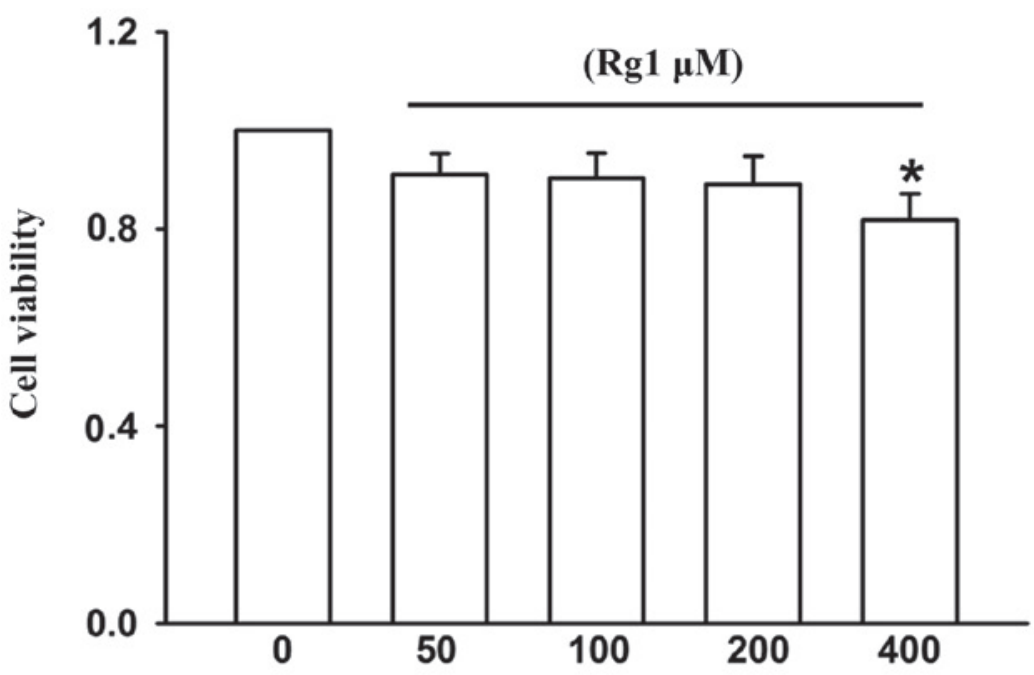

B

$\mathrm{Oh}$
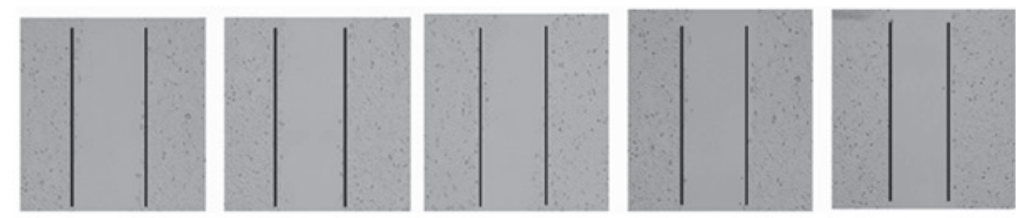

$24 \mathrm{~h}$
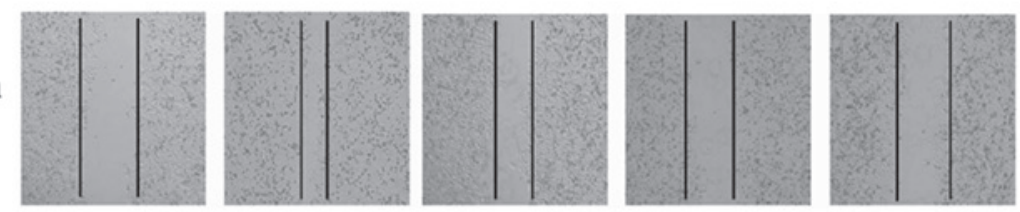

C

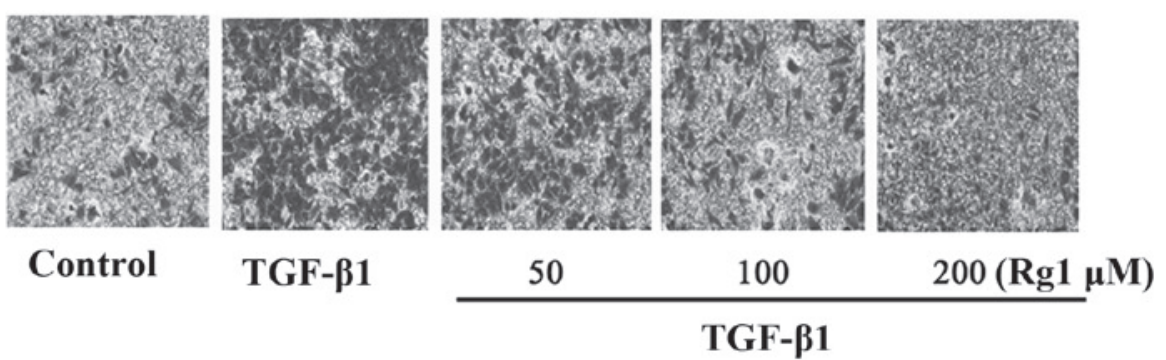

D

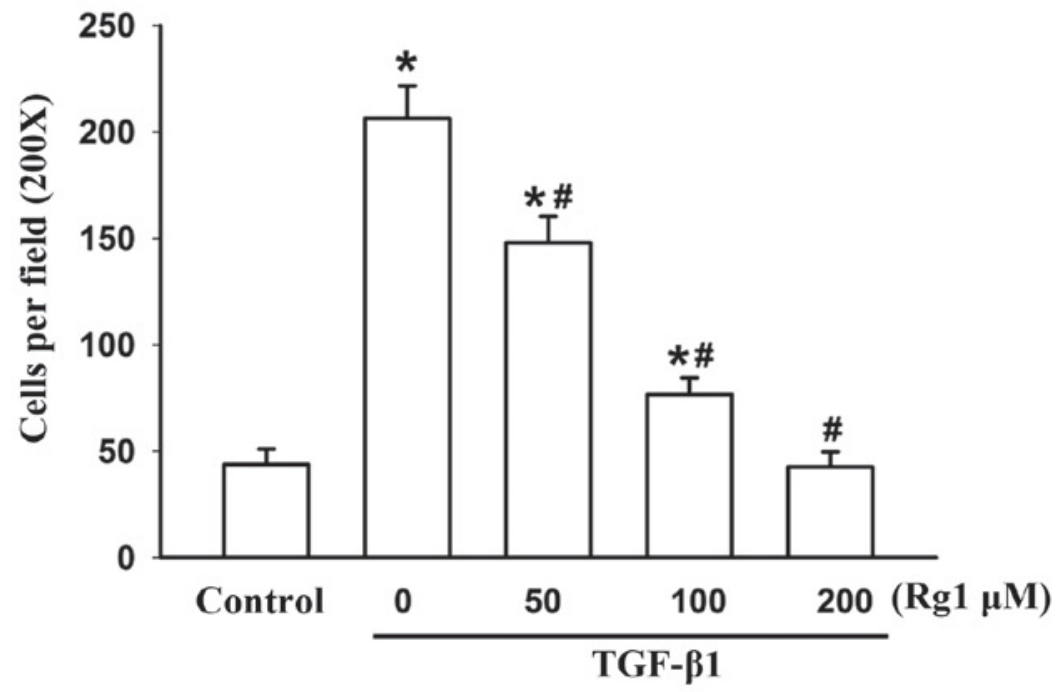

Figure 3. Rg1 inhibits TGF- $\beta 1$-induced cell invasion and migration. (A) Cells were treated with increasing concentrations of Rg1 (50-400 $\mu \mathrm{M})$ for $48 \mathrm{~h}$ and cell viability was assessed using a sulforhodamine B assay. Results are presented as the mean \pm standard error of the mean of three independent experiments; ${ }^{*} \mathrm{P}<0.05$ vs. untreated cells. (B) HepG2 cells were scratched with a pipette tip and then exposed to $50-200 \mu \mathrm{M} \mathrm{Rg} 1$ for $48 \mathrm{~h}$ in the presence of absence of $5 \mathrm{ng} / \mathrm{ml}$ TGF- $\beta 1$ for $24 \mathrm{~h}$. Results are representative of three independent experiments. (C and D) Invasive ability of HepG2 cells was assessed by Matrigel invasion assay. Cells were treated with 50-200 $\mu \mathrm{M} \mathrm{Rg} 1$ for $48 \mathrm{~h}$ in the presence or absence of $5 \mathrm{ng} / \mathrm{ml} \mathrm{TGF}-\beta 1$ for $24 \mathrm{~h}$. Results are presented as the mean \pm standard error of the mean of four independent experiments. " $\mathrm{P}<0.05$ vs. control; ${ }^{*} \mathrm{P}<0.05$ vs. TGF- $\beta 1$ group. TGF- $\beta 1$, transforming growth factor- $\beta 1$; Rg1, ginsenoside Rg1. 
A

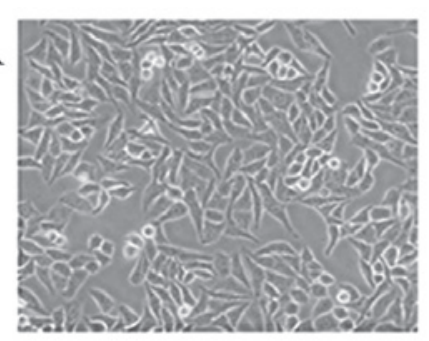

Control

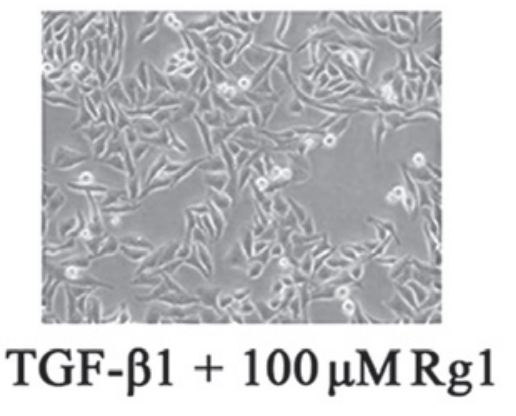

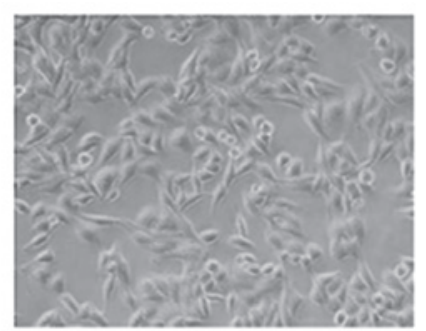

TGF- $\beta 1$

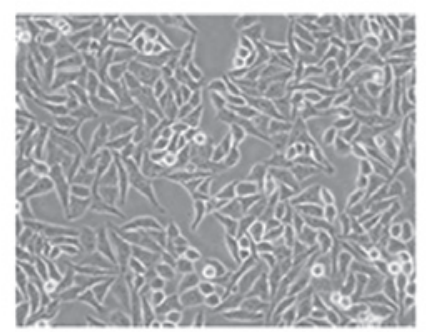

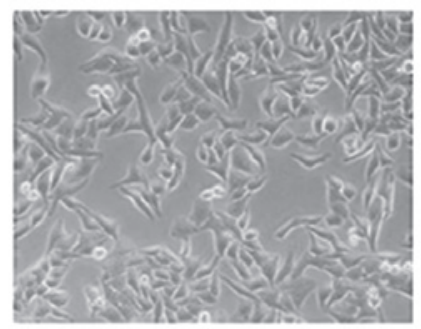

$\mathrm{TGF}-\beta 1+50 \mu \mathrm{M} \operatorname{Rg} 1$

\section{TGF- $\beta 1+200 \mu \mathrm{MRg} 1$}

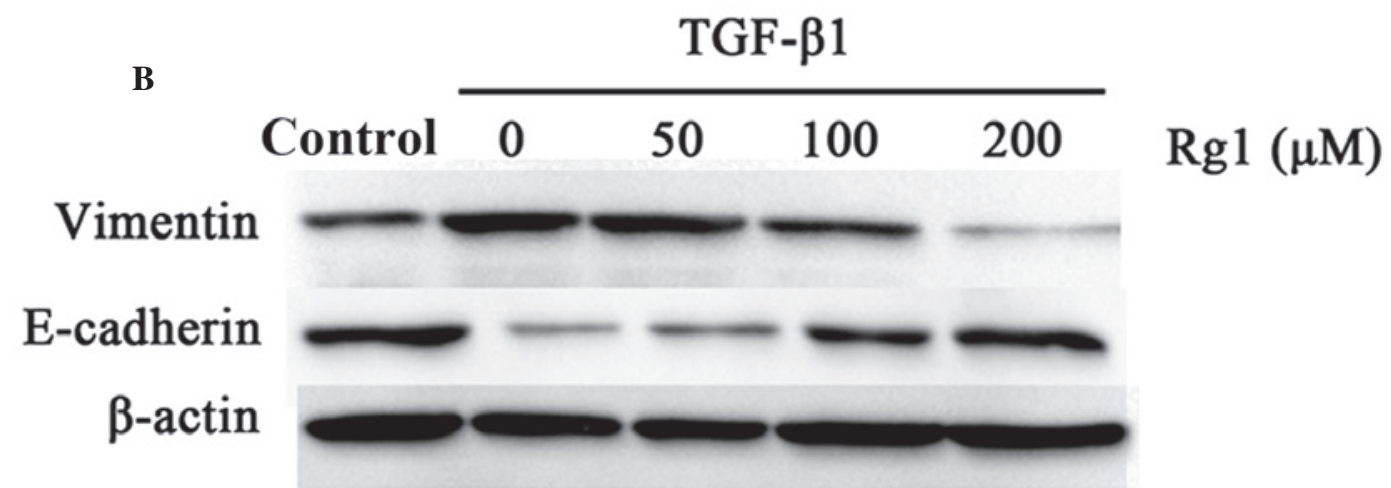

Figure 4. Rg1 regulates TGF- $\beta 1$-induced morphological alterations and epithelial to mesenchymal transition marker expression in HepG2 cells. Cells were treated with $\operatorname{Rg} 1(50-200 \mu \mathrm{M})$ for $48 \mathrm{~h}$ in the presence or absence of $5 \mathrm{ng} / \mathrm{ml}$ TGF- $\beta 1$ for $24 \mathrm{~h}$. (A) Representative images of TGF- $\beta 1$-induced morphological alterations in HepG2 cells. (B) Cellular protein levels of E-cadherin and vimentin were measured using western blotting. TGF- $\beta 1$, transforming growth factor- $\beta 1$; Rg1, ginsenoside Rg1.

Previous studies have demonstrated that ginsenoside Rg1 may exert anti-cancer properties $(13,18,26,27)$, however, this is the first study, to the best of our knowledge, to demonstrate that ginsenoside Rg1 may be a potential inhibitor of invasion and migration. The results of the transwell and wound-healing assays demonstrated that ginsenoside Rg1 inhibited TGF- $\beta 1$-induced cell invasion and migration in HepG2 cells. To further investigate how ginsenoside Rg1 suppresses TGF- $\beta 1$-induced cell invasion and migration, the effect of ginsenoside $\operatorname{Rg} 1$ on TGF- $\beta 1$-induced EMT was assessed. The results demonstrated that HepG2 cells exhibit a mesenchymal phenotype when exposed to TGF- $\beta 1$, but when exposed to ginsenoside Rg1 this effect was reversed and the cells exhibited a classical epithelial morphology. Ginsenoside Rg1 also increased the expression of the epithelial phenotype marker E-cadherin and repressed the expression of the mesenchymal phenotype marker vimentin.
These results suggest that ginsenoside Rg1 may prevent invasion and migration via inhibition of TGF- $\beta 1$-induced EMT in HepG2 cells.

In conclusion, the present study demonstrated that ginsenoside Rg1 was able to inhibit liver cancer cell invasion and migration in vitro by inhibiting TGF- $\beta 1$-induced EMT. This indicated that ginsenoside $\mathrm{Rg} 1$ may serve as a potential inhibitor in preventing the invasion and migration of human liver cancer.

\section{Acknowledgements}

The present study was supported by the China Postdoctoral Science Foundation (grant no. 20090461139); the Foundation of Bengbu Medical College (grant nos. Bykf13A11, Byycx1329 and 2013Byky1350); the Natural Science Foundation of 
the Provincial Education Department of Anhui (grant no. KJ2013A192); and the National Natural Science Foundation of Anhui (grant no. 1408085MH206).

\section{References}

1. Jemal A, Murray T, Ward E, et al: Cancer statistics, 2005. CA Cancer J Clin 55: 10-30, 2005.

2. Chaffer CL and Weinberg RA: A perspective on cancer cell metastasis. Science 331: 1559-1564, 2011.

3. Hanahan D and Weinberg RA: Hallmarks of cancer: the next generation. Cell 144: 646-674, 2011.

4. Chang CJ, Chao CH, Xia W, et al: $\mathrm{P} 53$ regulates epithelial-mesenchymal transition and stem cell properties through modulating miRNAs. Nat Cell Biol 13: 317-323, 2011.

5. Thiery JP, Acloque H, Huang RY, et al: Epithelial-mesenchymal transitions in development and disease. Cell 139: 871-890, 2009.

6. Voulgari A and Pintzas A: Epithelial-mesenchymal transition in cancer metastasis: mechanisms, markers and strategies to overcome drug resistance in the clinic. Biochim Biophys Acta 1796: 75-90, 2009

7. Lee JM, Dedhar S, Kalluri R, et al: The epithelial-mesenchymal transition: new insights in signaling, development, and disease. J Cell Biol 172: 973-981, 2006.

8. Zavadil J and Böttinger EP: TGF-beta and epithelial-to-mesenchymal transitions. Oncogene 24: 5764-5774, 2005.

9. Yang J and Weinberg RA: Epithelial-mesenchymal transition: at the crossroads of development and tumor metastasis. Dev Cell 14: 818-829, 2008.

10. Attele AS, Wu JA and Yuan CS: Ginseng pharmacology: multiple constituents and multiple actions. Biochem Pharmacol 58 1685-1693, 1999.

11. Lee EJ, Ko E, Lee J, et al: Ginsenoside Rg1 enhances CD4(+) T-cell activities and modulates Th1/Th2 differentiation. Int Immunopharmacol 4: 235-244, 2004.

12. Li CY, Deng W, Liao XQ, et al: The effects and mechanism of ginsenoside Rg1 on myocardial remodeling in an animal model of chronic thromboembolic pulmonary hypertension. Eur J Med Res 18: 16, 2013.

13. LiQF, Shi SL, Liu QR, et al: Anticancer effects of ginsenoside Rg1, cinnamic acid, and tanshinone IIA in osteosarcoma MG-63 cells: nuclear matrix downregulation and cytoplasmic trafficking of nucleophosmin. Int J Biochem Cell Biol 40: 1918-1929, 2008.

14. Liu J, Cai SZ, Zhou Y, et al: Senescence as a consequence of ginsenoside rg1 response on k562 human leukemia cell line. Asian Pac J Cancer Prev 13: 6191-6196, 2012.
15. Liu Q, Kou JP and Yu BY: Ginsenoside Rg1 protects against hydrogen peroxide-induced cell death in PC12 cells via inhibiting NF- $\kappa$ B activation. Neurochem Int 58: 119-125, 2011.

16. Qu DF, Yu HJ, Liu Z, et al: Ginsenoside Rg1 enhances immune response induced by recombinant Toxoplasma gondii SAG1 antigen. Vet Parasitol 179: 28-34, 2011.

17. Xu L, Chen WF and Wong MS: Ginsenoside Rg1 protects dopaminergic neurons in a rat model of Parkinson's disease through the IGF-I receptor signalling pathway. Br J Pharmacol 158: 738-748, 2009.

18. Li L, Wang Y, Qi B, et al: Suppression of PMA-induced tumor cell invasion and migration by ginsenoside $\mathrm{Rg} 1$ via the inhibition of NF- $\mathrm{BB}$-dependent MMP-9 expression. Oncol Rep 32: 17791786, 2014.

19. Ellenrieder V, Hendler SF, Boeck W, et al: Transforming growth factor betal treatment leads to an epithelial-mesenchymal transdifferentiation of pancreatic cancer cells requiring extracellular signal-regulated kinase 2 activation. Cancer Res 61: 4222-4228, 2001.

20. Chen J, Li Q, An Y, et al: CEACAM6 induces epithelial-mesenchymal transition and mediates invasion and metastasis in pancreatic cancer. Int J Oncol 43: 877-885, 2013.

21. Creighton CJ, Gibbons DL and Kurie JM: The role of epithelial-mesenchymal transition programming in invasion and metastasis: a clinical perspective. Cancer Manag Res 5: 187-195, 2013.

22. Polyak K and Weinberg RA: Transitions between epithelial and mesenchymal states: acquisition of malignant and stem cell traits. Nat Rev Cancer 9: 265-273, 2009.

23. Thiery JP and Sleeman JP: Complex networks orchestrate epithelial-mesenchymal transitions. Nat Rev Mol Cell Biol 7: 131-142, 2006.

24. Nagai T, Arao T, Furuta K, et al: Sorafenib inhibits the hepatocyte growth factor-mediated epithelial mesenchymal transition in hepatocellular carcinoma. Mol Cancer Ther 10: 169-177, 2011.

25. Shin JA, Hong OK, Lee HJ, et al: Transforming growth factor- $\beta$ induces epithelial to mesenchymal transition and suppresses the proliferation and transdifferentiation of cultured human pancreatic duct cells. J Cell Biochem 112: 179-188, 2011.

26. Yang JJ, Lim JY, Huang J, et al: The role of inherited TPMT and COMT genetic variation in cisplatin-induced ototoxicity in children with cancer. Clin Pharmacol Ther 94: 252-259, 2013.

27. Li J, Wei Q, Zuo GW, et al: Ginsenoside Rg1 induces apoptosis through inhibition of the EpoR-mediated JAK2/STAT5 signalling pathway in the TF-1/ Epo human leukemia cell line. Asian Pac J Cancer Prev 15: 2453-9, 2014. 